УДК 35.078.3:352.0

DOI https://doi.org/10.32844/2618-1258.2019.3-1.43

ШИЛО С.М.

\title{
ОСНОВНІ НАПРЯМИ ВДОСКОНАЛЕННЯ ЗАКОННОСТІ ТА ДИСЦИПЛІНИ В ДІЯЛЬНОСТІ ПУБЛІЧНОЇ АДМІНІСТРАЦІї
}

\begin{abstract}
У статті виокремлено найважливіші функції органів публічної адміністрації, що передбачають взаємодію влади та суспільства у формуванні політики, яка асоціюється із суспільним інтересом. У контексті опрацювання перспектив удосконалення діяльності публічної адміністрації автором наголошено на необхідності прийняття Етичного кодексу посадовця публічної адміністрації, який закріпить поняття честі та обов'язків працівників і буде основою збереження та підвищення професійної культури. Розкрито особливості юридичного механізму реалізації громадянином права на оскарження й виділено напрями адміністративного оскарження громадянами неправомірних дій і рішень публічної адміністрації та їх посадових осіб для зміцнення законності й дисципліни. Проаналізовано вимоги, які висуваються до основних форм оскарження (пропозиції, заяви, скарги). Наголошено, що держава повинна гарантувати кожній особі право на неупереджене та чесне вирішення iї справи протягом розумного строку. Особливу увагу слід приділяти процедурним гарантіям захисту прав приватних осіб, до числа яких належать такі: реалізація права приватної особи бути вислуханою перед прийняттям адміністративного акта; надання особі доступу до матеріалів справи, на основі яких приймається рішення; обмеження дискреційних повноважень органів; обов'язкове мотивування адміністративного акта, який може негативно вплинути на особу; визнання права приватної особи на допомогу та представництво в адміністративній процедурі; повідомлення особі порядку оскарження адміністративного акта та забезпечення правового захисту. Визначено, що органи публічної адміністрації мають виконувати такі найважливіші функції, які передбачають взаємодію влади та суспільства у формуванні політики, яка асоціюється із суспільним інтересом. До цих функцій належить артикуляція суспільних інтересів, публічний контроль діяльності влади та стану справ у державі, суспільстві, політично-економічній сфері, вплив на формування державної політики, політична освіта громадян. Діяльність органів публічної адміністрації має бути конструктивною, стабільною, відкритою та об'єктивною.
\end{abstract}

Ключові слова: законність, дисиипліна, публічна адміністраџія, посадова особа, орган виконавчої влади, міжнародний досвід.

The most important functions of the public administration authorities, which provide the interaction of the government and the society in forming policies that assume public interest are outlined in the article. In the context of working out the prospects for improving the ways of public administration, the author emphasizes the necessity of adopting the Ethics Code of a public administration official, which will consolidate the notion of honor and duties of employees and will be the basis for preserving and increasing professional culture. The peculiarities of the legal mechanism of realization of the person's right to appeal are discovered. The directions of administrative appeal of citizens towards unlawful actions and decisions of public administration and their officials in strengthening the legality and discipline are highlighted. The requirements for the main forms of appeal (proposals, claims, complaints) are analyzed. It is emphasized that the state must guarantee every person the right to an impartial and fair resolution of his or her case within a reasonable time. Particular attention should be paid to procedural

(C) ШИЛО С.М. - кандидат юридичних наук, доцент кафедри поліцейського права (Національна академія внутрішніх справ) 
safeguards to protect the rights of individuals, which include the exercise of the right of a private person to be heard before the adoption of an administrative act; giving the person access to the case files on which the decision is made; limitation of discretionary powers of bodies; mandatory motivation for an administrative act that may adversely affect the individual; recognition of the individual's right to assistance and representation in the administrative procedure; notification to the person of the procedure for appealing the administrative act and providing legal protection against it. It is determined that public administration bodies should perform the following important functions, which involve the interaction of government and society in the formation of policies that involve the public interest: articulation of public interests; public control of the activity of the authorities and the state of affairs in the state, society, political and economic sphere; influence on the formation of state policy; political education of citizens. Moreover, their activities should be constructive, stable, open and objective.

Key words: legality, discipline, public administration, official, executive body, international experience.

Вступ. В усі часи перед різними країнами світу поставало питання дотримання законності та дисципліни. Реформи адміністрації проводились через ці обставини. Завжди вироблялись різні концепції щодо реформування.

Наприклад, у Франції це проходило через зміни президентських республік, процес відбувався вертикально. Часто в процесі реформування європейських країн можна спостерігати те, як ці країни здійснювали модернізацію своїх систем публічного адміністрування. Як приклад можна навести структурні реформи 3 децентралізацією повноважень органів управління, запровадження підходів, що практикуються в економіці підприємств, на основі концепції Нового публічного адміністрування (New Public Management) та посилення самостійності організаційно-структурних підрозділів (так званих агенцій - Agencies). Детермінантами реформування були суспільні процеси та періодичні економічні рецесійні процеси. Натомість СРСР обрав інший шлях - жорстку централізацію влади в інтересах держави [1, с. 199; 2, с. 210].

Постановка завдання. Метою статті $є$ висвітлення основних напрямів вдосконалення законності та дисципліни в діяльності публічної адміністрації.

Результати дослідження. У літературі на цю тему з'явився вислів, що структури публічного адміністрування та його ефективність тісно взаємопов'язані (Organisations do matter). Проаналізувавши зарубіжну правову та історичну літературу, ми встановили, що в англійській, американській, польській науці і політичній практиці існувала яскраво виражена тенденція проголошувати класичне публічне адміністрування пережитком часу та таким, що має хиби в дотриманні законності й дисципліни. Науковці цих країн давали нове визначення співвідношенню між державою, сферою управління та суспільством. Йшлося про обмеження держави стрижневими функціями, широку приватизацію публічних інституцій та надання послуг ринковими референтами. У Японії у сфері публічного адміністрування почали широко вживатися підходи, запозичені з практики економічної діяльності приватних підприємств.

O.I. Черчатий [3, с. 67], В.М. Малиновський та Л. Пашко пропонують теж використовувати французькі напрацювання [4, с. 86-94]. П. Ворона акцентує увагу на японському, бельгійському, ізраїльському досвіді [5] тощо.

У теорії реформування публічної адміністрації цікавою є думка О.І. Черчатова та М. Дністрянського, за якою оптимальним для України $є$ триступеневий адміністративний поділ. На думку науковців, не слід докорінно змінювати сучасну публічну адміністративну систему та адміністративно-територіальну систему, а потрібно здійснювати зміни в окремих структурах у межах наявної ієрархії [6, с. 28-38].

Під час вивчення сучасних течій реформування публічної адміністрації як в Україні, так і за іії межами можна виділити п'ять напрямів удосконалення законності та дисципліни в діяльності публічної адміністрації.

До першого напряму належить створення нової правової бази, що буде регламентувати державне управління в Україні та створить чіткі вимоги до поняття законності й дисципліни. Другий напрям охоплює формування нових інститутів, реорганізаційних структур та інструментів здійснення державного управління, які забезпечать дотримання законності й дисципліни в діяльності публічних адміністрацій. Третій напрям містить кадрове забезпечення нової системи 
державного управління. Підготовка нової формації кадрів як у теоретичному, так і деонтологічному значенні приведе до поліпшення виконання посадових обов'язків та адекватного реагування на процеси в сучасному суспільстві. Четвертим напрямом $є$ зміцнення та формування нових фінансово-економічних основ забезпечення системи державного управління, що позитивно вплине на зменшення корупційного тиску і виведе на новий рівень відносини посадовця публічної адміністрації 3 громадянами. П'ятий напрям передбачає наукове та інформаційне забезпечення системи державного управління, формування механізмів науково-інформаційного моніторингу іiі функціонування.

Нині в Україні назріла реформа публічної адміністрації - це перетворення в системі публічного управління в інтересах громадян для вдосконалення взаємодії інститутів публічної адміністрації з громадянами, надання їм доброякісних управлінських послуг в економічній, правовій, соціально-культурній та інших сферах та посилення дотримання дисципліни і законності в діяльності публічної адміністрації.

Отже, реформування публічної адміністрації за напрямами вдосконалення, серед яких $є$ i дисциплінарний, та виконання законів $є$ забезпеченням і виконанням суспільного замовлення на ефективні, відповідальні й відкриті інститути виконавчої влади та місцевого самоврядування.

На нашу думку, слід починати реформування публічної адміністрації з удосконалення системи шляхом зобов'язання бездоганного виконання всіма законів і дотримання дисципліни, а вдосконалена і створена по-новому модель публічної адміністрації має бути інструментом інтеграції України до Європейського Союзу та інших економічних і політичних структур цивілізованого світу. Удосконалення слід проводити через ментальність народу. 3 огляду на те, що Україна $€$ однією з великих за територією держав серед країн Європи, тут неможливо втілити, наприклад, грузинський варіант реформи публічної адміністрації.

На жаль, прикладів недотримання вимог законів і дисципліни посадовцями публічної адміністрації можна привести безліч. Проте жоден посадовець не погодився самоусунутись внаслідок своїх порушень від посади. Навпаки, нормою стають образи від представників публічної адміністрації громадян, побиття, застосування сили до правоохоронців, брутальні вислови в бік інших посадовців, демонстративні порушення законів або взагалі подання до парламенту на реєстрацію законопроєктів, які призупиняли б дію антикорупційного, земельного законодавства. Існує в деяких випадках пряме лобіювання інтересів бізнес-груп всупереч законам.

Нова модель публічної адміністрації має бути вдосконаленою в рамках дотримання законності та дисципліни, відкритості та спрощеності процедур отримання послуг, посадова особа публічної адміністрації повинна стати помічником, а не керівником.

Основна мета удосконалення законності та дисципліни в діяльності публічної адміністрації - створити ефективну систему публічної адміністрації, яка б сприяла досягненню високого рівня життя громадян, соціальної стабільності та демократії.

Розширення меж та якості соціально-політичного представництва інтересів повноцінно може здійснюватися лише в публічній сфері. Публічна сфера - це сфера діалогу, спілкування, комунікації, це сфера договору щодо питань, що мають загальне значення. Лише коли атрибут публічності починає зникати або істотно зменшуватися, йому на зміну приходять закритість, корумпованість, клановість. Канали впливу на органи влади монополізуються сильними групами тиску, а громадянські інститути виявляються не в змозі донести свої інтереси до влади [7].

Для досягнення мети реформування адміністративних напрямів під час його проведення має впроваджуватись ідеологія служіння суспільству як принцип функціонування публічної адміністрації та повинні вирішуватись такі завдання:

1) формування стабільної та ефективної організації виконавчої влади;

2) створення системи спроможного місцевого самоврядування;

3) організація професійної, політично нейтральної та відкритої публічної цивільної служби (служба в органах виконавчої влади та органах місцевого самоврядування);

4) зміцнення становища громадян у відносинах з органами публічної адміністрації;

5) гарантування підконтрольності публічної адміністрації політичній владі та суспільству;

6) гарантування дотримання законності всіма учасниками відносин;

7) гарантування впливу громадян на посадовця, у тому числі і зняття його 3 посади $[8$, c. $46-47]$.

На нашу думку, зазначенні завдання мають вирішуватися шляхом:

1) законодавчого розмежування на основі Конституції повноважень між Урядом та главою держави, раціонального інституційного розмежування політичних та адміністративних функцій у системі виконавчої влади, удосконалення процедур діяльності органів публічної адміністрації; 
2) створення економічно самодостатніх суб'єктів місцевого самоврядування шляхом укрупнення сільських і селищних громад, запровадження повноцінного місцевого самоврядування на рівні району як додаткового (субсидіарного) рівня місцевого самоврядування, а також максимально можливої децентралізації публічних функцій і ресурсів;

3) проведення відмежування політичних посад від сфери публічної цивільної служби та встановлення правових механізмів захисту цивільних службовців від незаконних політичних впливів, запровадження відкритого конкурсного прийняття на цивільну службу та службового просування, а також вдосконалення системи управління державною цивільною службою;

4) певного правового регулювання адміністративної процедури (процедур), проведення спрямування діяльності публічних інституцій, зокрема, на надання публічних послуг, а також упровадження нових організаційних форм і стандартів якості послуг та удосконалення механізмів правового захисту громадян у відносинах з органами публічної адміністрації;

5) посилення контрольних функцій парламенту, місцевих рад, а також державного фінансового контролю, розвитку системи адміністративного судочинства, залучення громадськості до участі в управлінні публічними справами та до контролю за функціонуванням публічної адміністрації, частково і залучення засобів масової інформації.

В основу напрямів удосконалення законності та дисципліни в діяльності публічної адміністрації мають бути покладені засади організації та діяльності публічної адміністрації правових демократичних країн. Зокрема, це такі принципи:

1) верховенства права як пріоритету прав та свобод людини і громадянина, гуманізму та справедливості в діяльності публічної адміністрації (кожен посадовець повинен викарбувати їх у себе в душі);

2) законності як діяльності публічної адміністрації відповідно до повноважень і в порядку, визначеному законом, щодо недопущення правопорушень, жорсткого покарання та внесення до спеціальних баз у разі виявів корупції чи хабарництва;

3) відкритості як оприлюднення та доступності для громадян інформації про діяльність та рішення публічної адміністрації, а також надання публічної інформації на вимогу громадян, поширення інформації через мережу «Інтернет»;

4) пропорційності як вимоги щодо обмеження рішень публічної адміністрації метою, якої необхідно досягти, умовами її досягнення, а також обов’язком зважати на наслідки своїх рішень, дій і бездіяльності;

5) ефективності як обов’язку публічної адміністрації забезпечувати досягнення потрібних результатів у виконанні покладених на неї завдань у разі найменших витрат ресурсів;

6) підконтрольності як обов'язкового внутрішнього та зовнішнього, у тому числі судового, контролю за діяльністю публічної адміністрації;

7) відповідальності як обов’язку публічної адміністрації нести юридичну відповідальність за прийняті рішення, дії та бездіяльність [9, с. 541; 10, с. 722;11, с. 102].

Одним із напрямів удосконалення законності та дисципліни в діяльності публічної адміністрації є реформування Кабінету Міністрів України. Метою є забезпечення конституційного статусу Уряду як вищого органу в системі органів виконавчої влади, основним завданням якого є формування та реалізація державної політики.

Державна політика відображається у Програмі діяльності Кабінету Міністрів України, загальнодержавних програмах, програмах економічного і соціального розвитку АРК, областей, районів на міст, у державних цільових програмах, а також концепціях, стратегіях тощо.

Для підвищення відповідальності дотримання законності та дисципліни, а також ефективності роботи Кабінету Міністрів України необхідно, щоб його діяльність провадилася відповідно до стратегії, визначеної у Програмі діяльності Кабінету Міністрів України. Програма діяльності Кабінету Міністрів України має готуватися на період здійснення його повноважень. Обов'язковою є наявність п’ятирічних планів, у яких будуть виписані концепції та основні напрями роботи. При цьому Кабінет Міністрів України для зосередження на функції реалізації політики повинен максимально делегувати органам виконавчої влади нижчих рівнів або передати в інший легітимний спосіб свої повноваження адміністративного характеру [12, с. 279].

Удосконалення законності та дисципліни в діяльності публічної адміністрації у міністерському напрямі, на нашу думку, має бути головним.

Міністерства мають бути звільнені від невластивих функцій для усунення їх дублювання іншими органами виконавчої влади та підвищення ефективності роботи, недопущення порушень законності та дисципліни в діяльності публічної адміністрації. На нашу думку, сама внутрішня 
структура міністерств має бути переглянута 3 метою оптимізації складу та кількості департаментів. Слід вирахувати чисельність працівників за галузевими напрямами. Це значно посилить виконавську дисципліну та прискорить виконання законів.

Урядові органи як організаційно самостійні (автономні) структурні одиниці мають перебувати в системі міністерства відповідно до розподілу між міністрами сфер державної політики. Це означає відповідальність міністрів за діяльність урядових органів, але без втручання в їх поточну діяльність.

Одним із напрямів удосконалення законності та дисципліни в діяльності публічної адміністрації є запровадження незалежності функціонування органів влади, що визначені Конституцією України. Таке функціонування проводиться незалежно від міністерств.

Необхідно прийняти Етичний кодекс посадовця публічної адміністрації, який закріпить поняття честі та обов'язків. Цей документ буде підставою та важелем впливу для звільнення посадових осіб публічної адміністрації, які не бажають змінюватись та служити народу України, а не власним принципам, потребам.

Одним з напрямів удосконалення публічної адміністрації, який безпосередньо стосується кожного громадянина, $є$ раціональне та справедливе правове регулювання процедурних відносин органів публічної адміністрації з приватними особами.

Адміністративна процедура повинна бути простою та ефективною в межах закону. Коли адміністративний акт може стосуватися прав і законних інтересів інших приватних осіб (зацікавлених осіб) або коли необхідне вчинення додаткових процедурних дій (затребування документів або інформації, проведення слухання, експертизи тощо), слід застосовувати визначену законом формалізовану процедуру [13, с. 12].

Держава повинна гарантувати кожній особі право на неупереджене та чесне вирішення іiї справи протягом розумного строку. Особливу увагу слід приділяти процедурним гарантіям захисту прав приватних осіб (адресата адміністративного акта та/або зацікавленої особи), до яких належить реалізація права приватної особи бути вислуханою перед прийняттям адміністративного акта; надання особі доступу до матеріалів справи, на основі яких приймається рішення; обмеження дискреційних повноважень органів; обов'язкове мотивування (обгрунтування) адміністративного акта, який може негативно вплинути на особу; визнання права приватної особи на допомогу та представництво в адміністративній процедурі; повідомлення особі порядку оскарження адміністративного акта та забезпечення правового захисту. Крім того, кожній особі повинно гарантуватися право на відшкодування державою чи органами місцевого самоврядування збитків, завданих їй публічною адміністрацією.

Зазначені права мають бути закріплені на законодавчому рівні (в Адміністративно-процедурному кодексі) та стосуватися всіх органів публічної адміністрації. Принциповою новацією адміністративно-процедурного законодавства має стати врегулювання втручальних проваджень - випадків, коли прийняття рішення, яке стосується прав та законних інтересів конкретної приватної особи (осіб), здійснюється органом публічної адміністрації за власною ініціативою. Таке регулювання варто спрямувати на захист прав приватних осіб, урахування їх інтересів під час прийняття рішень. говорів.

Також потребують врегулювання відносини, пов'язані з укладенням адміністративних до-

Важливим елементом реформи публічної адміністрації є удосконалення адміністративного (досудового) механізму оскарження рішень, дій та бездіяльності органів публічної адміністрації.

Висновки. Отже, необхідно розвивати адміністративне оскарження як механізм захисту прав та законних інтересів приватних осіб у відносинах з публічною адміністрацією, оскільки такий механізм $є$ зручнішим, простішим та дешевшим для приватної особи. Крім того, він дасть змогу зменшити навантаження на судову систему.

Відсутність ієрархії у багатьох ланках системи публічної адміністрації та виняткова компетенція більшості органів публічної адміністрації вимагають перегляду традиційної концепції адміністративного оскарження як оскарження до органів вищого рівня.

Зокрема, доцільно передбачити право приватної особи звертатися до органу, що прийняв рішення, з клопотанням про його перегляд. Застосування цього механізму надає можливість уникнути конфлікту між владою та громадянином фактично у межах певного органу. Така процедура $є$ напрямом удосконалення законності й дисципліни під час перегляду рішень публічною адміністрацією.

Забезпечення вдосконалення законності та дисципліни в діяльності публічної адміністрації полягає також у проведенні реформи публічної адміністрації, вимагає комплексного інформу- 
вання про мету реформи або вдосконалення роботи, зміст ії основних заходів, очікувані результати та перебіг реформи. Необхідно забезпечити зворотний зв'язок і підтримку з боку основних адресатів реформи, а також суспільства в цілому.

На нашу думку, слід зосередитись на таких інститутах:

- інституті громадянського суспільства;

- засобах масової інформації;

- особах, які обіймають політичні посади всіх рівнів;

- державних службовцях та посадових особах місцевого самоврядування.

Таким чином, органи публічної адміністрації мають виконувати такі найважливіші функції, які передбачають взаємодію влади та суспільства у формуванні політики, яка асоціюється із суспільним інтересом. Цими функціями є такі: 1) артикуляція суспільних інтересів; 2) публічний контроль діяльності влади та стану справ в державі, суспільстві, політично-економічній сфері; 3) вплив на формування державної політики; 4) політична освіта громадян. Діяльність органів публічної адміністрації має бути конструктивною, стабільною, відкритою та об’єктивною.

Отже, вироблення певної стратегії та створення нових критеріїв оцінювання механізмів впливу на реальну владу може суттєво поліпшити якість державного управління та позитивно вплинути на ефективний розвиток публічної політики.

\section{Список використаних джерел:}

1. Циганов О.Г. Особливості правового регулювання надання адміністративних послуг у країнах Європейського Союзу та в Україні. Теорія та практика адаптації законодавства України до законодавства $C C$ : матеріали міжнар. наук.-практ. конф., м. Київ, 8 черв. 2018 р. Київ : Видавничий дім «Гельветика», 2018. С. 198-201.

2. Шило С.М. Забезпечення дисципліни та законності в діяльності публічної адміністрації : дис. ... канд. юрид. наук : 12.00.07. Дніпропетровськ, 2014. 223 с.

3. Черчатий О.І. Оптимізація діяльності публічної адміністрації України на регіональному рівні в умовах євроінтеграції : дис. ... канд. юрид. наук : 25.00 .02 «Механізми державного управління». Харків, 2011. 224 с.

4. Малиновський В.Я. Реформування територіальної організації влади України в контексті досвіду Франції. Вісник Наиіональної академії державного управління при Президентові України. 2007. № 1. С. 86-94.

5. Зарубіжний досвід організації та роботи місцевої влади : монографія / Власенко О.В., Ворона П.В., Пухтинський М.О. та ін. ; за заг. ред. П. Ворони. Полтава : ПолтНТУ, 2009. 288 с.

6. Дністрянський М. Чи потрібно реформувати адміністративно-територіальний устрій України? (політико-географічний погляд). Політична думка. 2001. № 1-2. С. 28-38.

7. Соколов А.В. Сучасні підходи до оцінки якості державного управління. Державне управління: удосконалення та розвиток. 2014. № 4. URL: http://http://www.dy.nayka.com. ua/?op $=1 \& \mathrm{z}=901$.

8. Малиновський В.Я. Сучасний стан і перспективи реформування публічної адміністрації в Україні. Вісник держсавної служби України. 2017. № 3. С. 42-48.

9. Курс адміністративного права України : підручник / за ред. В.В. Коваленка. Київ : Юрінком Інтер, 2012. 808 с.

10. Адміністративне право України : підручник / за заг. ред. С.В. Ківалова. Одеса : Юридична література, 2003. 896 с.

11. Коломоєць Т.О. Адміністративне право України : підручник. Київ : Істина, 2012. 528 с.

12. Олійник Д.В. Сучасні методи оцінки ефективності діяльності органів державного управління. Ефективність державного управління. 2013. Вип. 34. С. 275-283.

13. Авер'янов В.Б. Значення адміністративних процедур у реформуванні адміністративного права. Часопис Київського університету права. 2009. № 3. С. 8-14. 